\title{
Whose pay should be cut in economic crises? Consumers prefer firms that prioritize paying employees over CEOs
}

\author{
Serena F. Hagerty ${ }^{1 \star}$ (D), Bhavya Mohan ${ }^{2}$ (D) and Michael I. Norton ${ }^{1}$ \\ ${ }^{1}$ Harvard Business School, Harvard University, Boston, MA, USA and ${ }^{2}$ University of San Francisco, \\ San Francisco, CA, USA \\ ${ }^{\star}$ Correspondence to: E-mail: shagerty@hbs.edu
}

(Received 11 September 2020; revised 30 August 2021; accepted 7 September 2021)

\begin{abstract}
Four experiments examine the impact of a firm deciding to no longer pay salaries for executives versus employees on consumer behavior, particularly in the context of the COVID-19 pandemic. Study 1 explores the effect of announcing either pay cessations or continued pay for either CEO or employees, and shows that firms' commitment to maintaining employee pay leads to the most positive consumer reactions. Study 2 examines the effects of simultaneously announcing employee and CEO pay cessations: consumers respond most positively to firms prioritizing employee pay, regardless of their strategy for CEO pay. Moreover, these positive perceptions are mediated by perceptions of financial pain to employees, more than perceptions of CEO-to-worker pay ratio fairness. Study 3, using an incentive-compatible design, shows that firms' commitment to paying employees their full wages matters more to consumers than cuts to executive pay, even when those executive pay cuts lead to a lower CEO-to-worker pay ratio. Study 4 tests our account in a non-COVID-19 context, and shows that consumers continue to react favorably to firms that maintain employee pay, but when loss is less salient, consumers prioritize cutting CEO pay and lowering the CEO-to-worker pay ratio. We discuss the implications of our results for firms and policymakers during economic crises.
\end{abstract}

Keywords: employee furloughs; CEO pay cuts; pay ratios; purchase intention

\section{Introduction}

In March of 2020, retailers, food service providers, airlines, and factories around the world shut down as the coronavirus pandemic spread (Horowitz, 2020). As a result of the economic fallout, many companies announced strategies for weathering the pandemic, which included new plans of compensation for both employees and upper management. However, there was heterogeneity in firm strategies. A number of firms furloughed thousands of employees, cutting pay to zero even though employees technically retained their jobs (Vasel, 2020). Consumer-facing retail employees were 
hit particularly hard - for instance, Kohl's furloughed 122,000 store employees without any pay, while Gap Inc. furloughed 80,000 store employees without pay (Smith, 2020). Others focused on maintaining employee pay (Cappiello, 2020), as when Nike Inc. announced all employees would continue to be paid in full during store closures (de León \& Geller, 2020), and when Columbia Sportswear pledged that each of the company's 3500 retail employees would continue to receive their full salary through the pandemic (Lee, 2020). Still, other firms focused on cutting pay for members of upper management (Trentmann \& Broughton, 2020). Some decided to furlough employees without pay and also cut pay for upper management; for example, Kohl's and Gap Inc. also announced salary reductions to executive team compensation (Chochrek, 2020; Smith, 2020). While some instituted pay cuts only for upper management: Columbia Sportswear announced a CEO salary reduction to $\$ 10,000$ while pledging to maintain employee wages (Lee, 2020).

However, even though top executives were advised by the Harvard Business Review that, 'As CEO, you should take the largest salary cut yourself ...' (Tarki et al., 2020), not all firms followed suit. When J.C. Penney furloughed the majority of their 95,000 store employees without pay, no executive pay cuts were announced (Smith, 2020). As firms furloughed employees without pay, some executives even received additional bonuses, or large equity awards at low stock valuations (DiNapoli \& Kerber, 2020). Build-A-Bear furloughed $90 \%$ of its 4,300 store employees without pay and publicly announced a $20 \%$ executive pay cut; 2 weeks later, however, top executives received stock grants equivalent to the value of their pay cuts, effectively preserving their salaries (DiNapoli \& Kerber, 2020).

We explore consumer reactions to firms' decisions for CEO versus employee pay, because, while announcing executive pay cuts during a crisis is seen as a reputational move (during the early months of the pandemic, more than 300 public companies did so), far fewer firms publicized a commitment to paying their retail employees (Cappiello, 2020; Trentmann \& Broughton, 2020). We, therefore, explore the relative effectiveness of firm decisions to cease or maintain both employee and executive pay during a crisis on consumer attitudes and behavior.

\section{Conceptual background}

Comparisons of CEO to average or median employee compensation have received increased attention in recent years (McGregor, 2013). In the last decade, the wage growth of employees lagged, compared to executive wage growth, even amidst record high economic growth and low unemployment rates (Gould, 2019). CEO pay, however, increased a third more quickly than the U.S. stock market between 1978 and 2018 (Mishel \& Wolfe, 2019). These staggering discrepancies have not gone unnoticed. Indeed, a strict CEO pay ratio limit of 50:1 for firms receiving government aid was in the first stimulus relief package put forward to the United States Congress in 2020 (Anderson \& Pizzigati, 2020).

Previous survey research suggests that both consumers and citizens hold strong beliefs about the fairness of the gap between employees and management. For instance, Americans report an 'ideal' ratio of CEO pay to unskilled worker pay of 7:1 (Kiatpongsan \& Norton, 2014), dramatically lower than the actual average pay 
ratio across US firms of 287:1 (AFL-CIO, 2019). Moreover, recent research shows that consumers prefer firms with lower CEO-to-worker pay ratios, and that the disclosure of high pay ratios can negatively affect actual purchase behavior, via diminished perceptions of fairness (Benedetti \& Chen, 2018; Mohan et al., 2018).

Past research suggests that even when employees are paid significantly higher wages, this does not mitigate the preference for lower pay ratios: in one study, regardless of whether employees made an annual salary of $\$ 22,000$ or $\$ 86,000$, participants rated a firm more favorably if there was a low (vs. high) CEO pay ratio, suggesting that a preference for a low ratio is not always driven by a demand for significantly higher employee pay, but rather a more general preference for fair wage ratios (Benedetti \& Chen, 2018). These findings suggest that consumers may respond most favorably to firms that commit to reducing the CEO pay ratio. Importantly, however, this past research does not independently assess the extent to which consumer preferences are driven by the treatment of employees versus the treatment of CEOs. Relatedly, prior research has examined preferences for pay in the context of static pay ratios, not in the context of changes in pay (wage cuts and employee furloughs)

How might consumers react to a firm's decision to stop paying employee wages? Previous research suggests that consumers are, in fact, sensitive to a firm's treatment of employees (Creyer \& Ross, 1996; Hiscox et al., 2011; Paharia et al., 2013; Peloza et al., 2013); in one study, signage ensuring good working conditions led consumers to pay up to $40 \%$ more for these labeled products (Prasad et al., 2004). Therefore, we predict that consumers will respond more favorably to companies that commit to maintaining employee pay, relative to those who cease paying employees.

Furthermore, when evaluating a firm's decision for both CEO and employee pay simultaneously, particularly with respect to pay cuts and furloughs, we predict consumers will be more sensitive to decisions about employee pay. For consumers, a loss to retail employees (in the form of a pay cessation during a furlough) likely looms larger than the gains from cutting CEO pay. Because employees earn less than CEOs, pay cessations may be perceived to be a greater loss for employees comparatively, leading observers to be more sensitive to losses for employees (vs. CEOs). There is a wide gap in personal financial impact when comparing the effects of a CEO pay cut to an unpaid employee furlough (Trentmann \& Broughton, 2020). In 2018, the average American CEO made \$14.5 million dollars, compared to an employee average of $\$ 39,888$ (Campbell, 2019). Thus, a hypothetical across the board $50 \%$ pay cut leaves the CEO with $\$ 7.25$ million, but reduces the average employee to a salary below the minimum wage, taking them below the poverty line. We note that in this article, we focus specifically on contexts where employee jobs are technically preserved, but pay is cut to zero. We believe that this particular context best reflects what predominantly happened during the COVID-19 when retailers furloughed thousands of employees (Vasel, 2020).

Consumers can likely relate more closely with retail employees than CEOs; thus, they might have an accurate judgment of the financial pain a furloughed retail employee would experience. We predict that this sensitivity to employee financial pain mediates the negative effects of salary cuts on purchase intention, over and above general preferences for greater wage equity, or wage fairness. Therefore, we propose that a firm's treatment of its employees - specifically, the decision not to furlough employees without pay 
- may matter more to consumers than pay decisions for executives, over and above the fact that executive pay cuts may produce a lower (and 'fairer') CEO-to-worker pay ratio.

This will be particularly true when loss of wages is salient to consumers, such as during the COVID-19 pandemic. According to Gallup polls, in 2019, only 8\% of Americans feared losing their job; that number was up to a record-high $25 \%$ by April 2020, due to the economic fallout of the pandemic (Brenan, 2020). By May 2020, the unemployment rate in the USA had jumped to four times the pre-COVID rate at the start of the year (Bureau of Labor Statistics, 2021). Even by the end of 2020, the unemployment rate remained twice as high as pre-COVID rates (Bureau of Labor Statistics, 2021). In such a crisis, when losses loom and furloughs without pay are not directly tied to personal performance, we predict that consumers will be particularly sensitive to employee pay. While reducing the CEO-to-worker pay ratio may be a priority in times of normal economic growth, we predict that a firm's decision to avoid employee furloughs without pay may matter more to consumers than cuts to executive pay.

\section{Overview of studies}

Four experiments (including an incentive-compatible study) examine consumers' reactions to ceasing versus maintaining pay for both executives and employees. Study 1 provides experimental evidence that consumers reward firms for continuing to pay employees above and beyond ceasing CEO pay. These effects are mediated by perceptions of financial pain to employees. Study 2 examines the effects of simultaneously announcing employee and CEO pay cessations, and shows that consumers respond most positively to firms which prioritize paying employees, regardless of CEO pay level. These positive perceptions are mediated by perceptions of financial pain to employees, more than perceptions of CEO-to-worker pay ratio fairness. Study 3 demonstrates these effects in an incentive-compatible context and shows that firms' commitment to paying employees their full wages matters more to consumers than pay decisions for executives. Finally, Study 4 shows that while consumers always favor companies that maintain employee pay, outside the context of COVID-19, consumers prioritize cutting $\mathrm{CEO}$ pay and lowering the CEO-to-worker pay ratio.

\section{Study 1}

The key objective of Study 1 is to examine whether consumers' purchase intentions are affected by disclosure of a firm's decision to cease or to continue to pay the salaries of either the CEO or the retail employees. Study 1 also examines a potential mediator - the role of perceptions of financial pain to employees as a result of these salary decisions. Furthermore, this study considers the role of a consumer's own wage experience during COVID-19.

\section{Method}

Design and participants

Participants $(N=383 ; 52 \%$ female; age: $M=43.28$ years, $\mathrm{SD}=14.93)$ were recruited through an Amazon Mechanical Turk Prime Panel and paid a flat rate for 
compensation. This study used a 2 (employee type: retail employee vs. CEO) $\times 2$ (salary: paid fully vs. cut fully) between-subject design. Participants were asked to imagine that they were looking to buy a new set of headphones from a well-known retailer. Participants were then asked to 'Imagine that you then learn that due to the COVID-19 epidemic, the well-known retailer closed down a number of their physical stores.' Participants then read about the company's decision regarding the salary of either the retail employees (retail employee condition) or the salary of the CEO (CEO condition). Participants read that the company either 'continued to pay their salary' (paid fully condition) or decided to 'no longer pay their salary' (cut fully condition).

\section{Measures}

All participants were first asked 'Given the opportunity, how likely are you to purchase the headphones from this retailer?' ( $1=$ Not at all likely, $7=$ Very likely). Participants were then asked 'How much pain does the company's decision cause the retail employees?' and asked the same question about the CEO ( $1=$ None at all; $7=$ Very much). Participants were also asked if their own wages had been negatively affected by the COVID-19 virus. In total, 173 (45\%) of our participants answered 'Yes,' while 210 (55\%) answered 'No'. Finally, in this and subsequent studies, participants were asked a set of demographic questions including age, gender, education level, and monthly household income.

\section{Results}

Willingness to buy

A 2 (employee type: retail employee vs. CEO) $\times 2$ (salary: paid fully vs. cut fully) ANOVA analysis on willingness to buy revealed no significant main effect of employee type or of salary decision, but a significant interaction, $F(1,382)=21.34$, $\mathrm{p}<0.001, \eta_{\mathrm{p}}^{2}=0.05$. Participants who read about retail employees were significantly less likely to buy the headphones when retail employee salaries were not paid $(M$ $=4.54, \mathrm{SD}=2.12)$ compared to when retail employee salaries were still paid $(M=$ $5.63, \mathrm{SD}=1.70), t(190)=3.94, \mathrm{p}<0.001, d=0.57$. Participants who read about the CEO were more likely to buy the headphones when CEO salary was not paid $(M$ $=5.09, \mathrm{SD}=1.79)$ compared to when $\mathrm{CEO}$ salary was still paid $(M=4.39, \mathrm{SD}=$ $2.00), t(189)=-2.59, \mathrm{p}=0.01, d=0.37$. Importantly, participants were significantly more likely to buy the headphones when informed that employee salaries were still paid than when informed CEO salary was not paid, $t(190)=2.12, \mathrm{p}=0.04, d=$ 0.31 , see Figure 1 . These results hold when controlling for participant household income and controlling for whether their own wages were affected by COVID-19 (all ps $<0.05$ ).

\section{Perception of pain to employees versus CEO}

A 2 (employee type: retail employee vs. CEO) $\times 2$ (salary: paid fully vs. cut fully) ANOVA analysis on perceived pain of retail employees revealed a significant main effect of employee type, $F(1,382)=5.66, \mathrm{p}=0.02, \eta_{\mathrm{p}}^{2}=0.02$, a significant main effect of salary decision, $F(1,382)=19.54, \mathrm{p}<0.001, \eta_{\mathrm{p}}^{2}=0.05$, and a significant interaction 


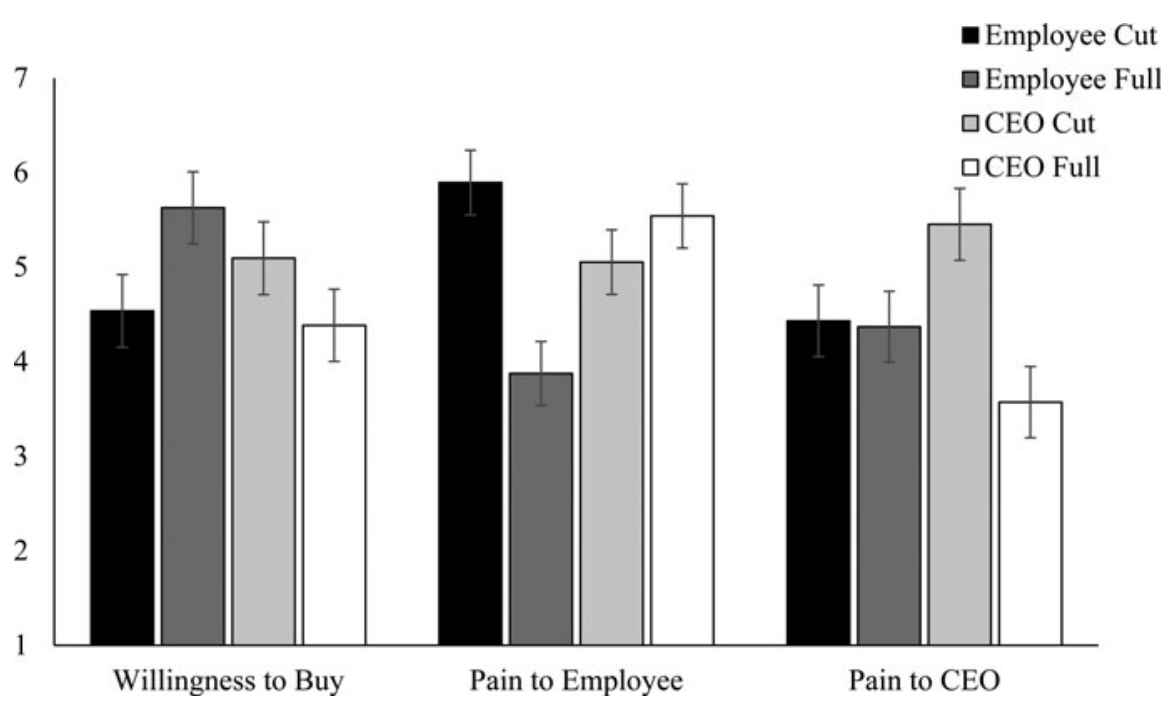

Figure 1. Consumers Respond More Favorably to the Firm that Maintains Employee Salaries. Error Bars Show $95 \% \mathrm{Cl}$.

between employee type and salary decision, $F(1,382)=52.52, \mathrm{p}<0.001, \eta_{\mathrm{p}}^{2}=0.12$. Participants perceived employees to experience greater pain when their salaries were not paid $(M=5.90, \mathrm{SD}=1.43)$ than when their salary was paid $(M=3.88, \mathrm{SD}$ $=2.09), t(190)=-7.81, \mathrm{p}<0.001, d=1.12$. However, participants perceived employees to experience greater pain when the CEO's salary was paid $(M=5.54, \mathrm{SD}=1.50)$ than when the CEO's salary was not paid $(M=5.05, \mathrm{SD}=1.67), t(189)=-7.81, \mathrm{p}=$ $0.04, d=0.31$. Importantly, employee pain was perceived to be the lowest when their salaries were paid relative to all other conditions ( $\mathrm{ps}<0.001$ ).

There was no significant difference in perceived pain of CEO when participants read that retail employee salaries were paid $(M=4.37, \mathrm{SD}=1.86)$ compared to when they read retail employee salaries were not paid $(M=4.43, \mathrm{SD}=1.96), t(190)$ $=-0.22, \mathrm{p}=0.83, d=0.03$. However, participants perceived CEO pain to be significantly higher when CEO salary was not paid $(M=5.45, \mathrm{SD}=1.54)$ relative to when CEO salary was paid $(M=3.57, \mathrm{SD}=2.12), t(189)=-7.00, \mathrm{p}<0.001, d=1.02$. As predicted, a salary cessation was perceived as more painful for retail employees $(M=5.90, \mathrm{SD}=1.43)$ than for the $\mathrm{CEO}(M=5.45, \mathrm{SD}=1.54), t(188)=2.05$, $\mathrm{p}=0.04, d=0.30$.

\section{Mediation analysis}

We conducted a moderated mediation analysis, with employee type as the moderator, to explore the indirect effects of perceived employee pain versus perceived CEO pain on the relationship between salary information and willingness to buy. Overall, perceived pain of the employee had a significant negative indirect effect in the retail employee conditions (indirect effect: $-0.47,95 \%$ CI $[-0.75,-0.25]$ ) and a significant positive indirect effect in the CEO conditions (indirect effect: $0.11,95 \%$ CI [0.02, 
0.27]; index of moderated mediation: $0.59,95 \%$ CI $[0.30,0.94])$. That is, participants were less likely to buy when perceived pain of employees was high, both when employee pay was ceased and when CEO pay was maintained. In contrast, while perceived pain of the $\mathrm{CEO}$ had a significant indirect effect in the CEO conditions (indirect effect: $0.57,95 \%$ CI $[0.35,0.85])$, there was no significant indirect effect in the employee conditions (indirect effect: $0.02,95 \%$ CI $[-0.15,0.19]$; index of moderated mediation: $0.55,95 \%$ CI $[0.29,0.92])$. That is, participants were more willing to buy when CEO pain was perceived to be high as a result of CEO pay cessation. Overall, these results suggest that consumers may be more likely to purchase from a firm when perceived pain to employees is low, and when perceived pain to CEOs is high.

\section{Discussion}

Study 1 suggests that consumers respond most favorably when a firm decides to continue to pay retail employee salaries during a crisis. Overall, consumers were more responsive to information about retail employee salaries than to information about the CEO's salary. These effects were mediated by perception of financial pain to the retail employees, and held even when controlling for whether or not a consumer's own wages were affected by COVID-19.

\section{Study 2}

Study 2 examines the effects of announcing employee and CEO pay cessations simultaneously. As in Study 1, participants read about a firm's decision regarding salaries in the wake of COVID-19. However, in this design, participants read about the firm's decision for both the retail employees and the CEO. We examine the effect of salary information on a consumer's propensity to buy from that firm and the underlying role of perceptions of financial pain to employees and perceptions of wage fairness. We suggest that perceptions of fairness will be more responsive to the CEO-to-worker pay ratio, while perceptions of pain to employees will be more responsive to information about employee pay, regardless of CEO pay. Therefore, if consumers care more about maintaining employee pay than reducing the wage ratio, we would expect perceived pain to employees to be a stronger predictor of willingness to buy than perceived pain to CEO or perceived fairness of the wages.

\section{Method}

\section{Design and participants}

Participants $(N=630 ; 63 \%$ female; age: $M=46.08$ years, $\mathrm{SD}=16.48)$ were recruited through an Amazon Mechanical Turk Panel and paid a flat rate for compensation. Study 2 used a 2 (retail employee salary: paid fully vs. cut fully) $\times 2$ (CEO salary: paid fully vs. cut fully) between-subject design. All participants were given initial instructions to imagine that they were looking to purchase a new pair of shoes and found a high-quality pair at a price point below their budget being sold online by a well-known retailer. Participants then read 'Imagine that you then learn that due to the COVID-19 epidemic, the well-known retailer closed down their physical stores. 
In this company, the CEO's salary costs $\$ 14$ million dollars a year. Continuing to pay all employees their regular salary would cost \$14 million dollars.'

All participants then read information about the status of both the retail employees and the CEO salaries at this company. For retail employee salary information, participants read either that 'The company has decided to continue paying their retail employees their salaries' (retail employee paid fully) or 'The company has decided to stop paying their retail employees their salaries' (retail employee cut fully). For CEO salary information, participants read either that 'The company has decided to continue paying their CEO their salary' (CEO paid fully) or 'The company has decided to stop paying their CEO their salary' (CEO cut fully). Information about employee salaries and CEO salary were presented in randomized order.

\section{Measures}

As the primary dependent measure, all participants were asked 'Given the opportunity, how likely are you to purchase the shoes from this retailer?' ( $1=$ Not at all likely; 7 = Very likely). As in Study 1, participants were asked how much pain the company's decision causes the retail employees and the CEO, separately $(1=$ None at all; $7=$ Very much). As a secondary measure, they were asked how fair they thought the wage the retailer pays its $\mathrm{CEO}$ is and how fair the wages for retail employees are ( $1=$ Not at all fair; $7=$ Extremely fair $)$.

\section{Results}

\section{Willingness to buy}

A 2 (retail employee salary: paid fully vs. cut fully) $\times 2$ (CEO salary: paid fully vs. cut fully) ANOVA analysis on willingness to buy revealed a main effect of retail employee pay, $F(1,629)=199.27, \mathrm{p}<0.001, \eta_{\mathrm{p}}^{2}=0.24$, such that participants were more likely to buy when retail employee salaries were still being paid. There was also a main effect of CEO pay, $F(1,629)=10.58, \mathrm{p}=0.001, \eta_{\mathrm{p}}^{2}=0.02$, such that participants were more likely to buy when the CEO salary was not paid. There was also a significant interaction, $F(1,629)=4.28, \mathrm{p}=0.04, \eta_{\mathrm{p}}^{2}=0.01$, revealing that not paying the CEO increased willingness to buy (WTB) only when retail employee salaries were also not paid. If retail employee salaries were not paid, participants indicated greater WTB if CEO salary was also not paid $(M=3.96, \mathrm{SD}=2.06)$ compared to when CEO salary was paid in full $(M=3.16, \mathrm{SD}=2.19), t(314)=-3.3, \mathrm{p}=0.001, d=$ 0.38 . However, if retail employee salaries were still being paid, participants indicated the same WTB whether CEO salary was paid $(M=5.59, \mathrm{SD}=1.51)$ or if CEO salary was not paid $(M=5.76, \mathrm{SD}=1.61), t(312)=-1.01, \mathrm{p}=0.32, d=0.11$; see Figure 2 .

\section{Fairness perceptions}

Full salaries for the retail employees were seen as more fair $(M=4.90, S D=1.78)$ than if retail employee salaries were not paid $(M=3.59, \mathrm{SD}=2.01), t(628)=8.68, \mathrm{p}=$ $0.001, d=0.69$. Ceasing the CEO salary was only perceived as marginally more fair $(M=3.91, S D=2.05)$ than paying the CEO their full salary $(M=3.62, \mathrm{SD}=2.20), t$ $(628)=-1.67, \mathrm{p}=0.10, d=0.14$. 


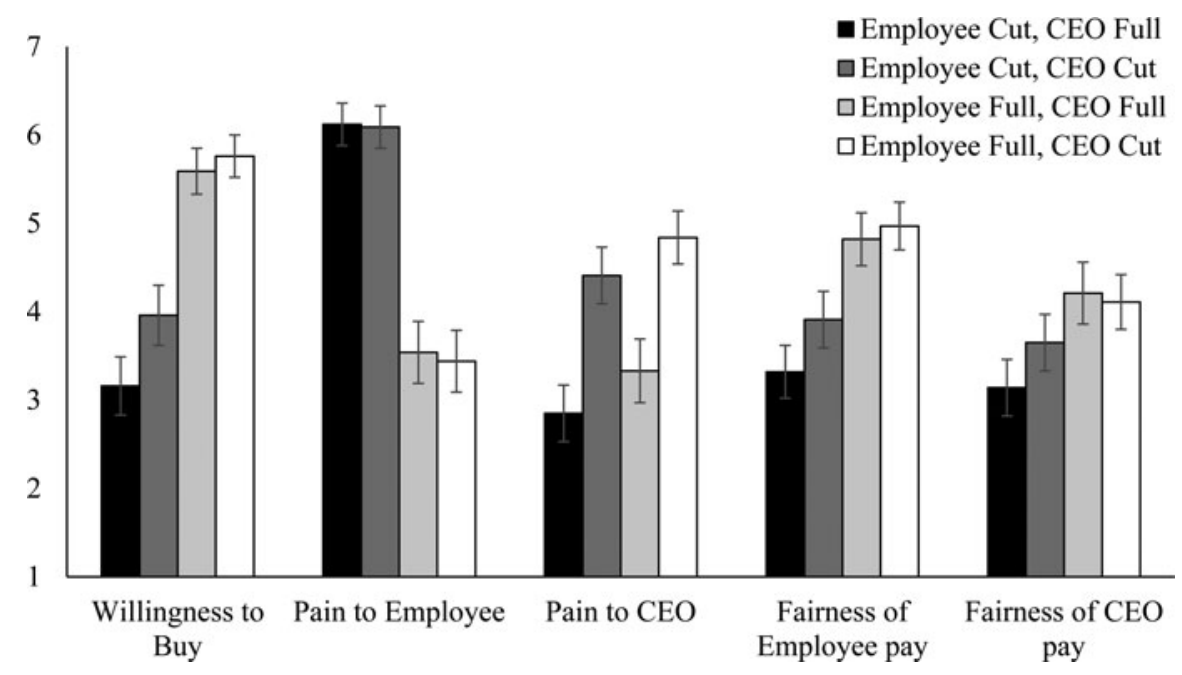

Figure 2. Consumers Respond More Favorably to the Firm that Maintains Employee Salaries, Regardless of CEO Pay Decision. Error Bars Show 95\% Cl.

\section{Perceptions of pain}

A 2 (retail employee salary: paid fully vs. cut fully) $\times 2$ (CEO salary: paid fully vs. cut fully) ANOVA analysis on perceived pain to employees revealed a main effect of retail employee pay, $F(1,629)=299.78, \mathrm{p}<0.001, \eta_{\mathrm{p}}^{2}=0.32$, no effect of CEO pay, $F(1,629)$ $=0.17, \mathrm{p}=0.68, \eta_{\mathrm{p}}^{2}<0.001$, and no significant interaction between retail employee pay and CEO pay, $F(1,629)=0.06, \mathrm{p}=0.81, \eta_{\mathrm{p}}^{2}<0.001$. As expected, participants perceived a salary cessation to be more painful for retail employees $(M=6.10, \mathrm{SD}=1.50)$ than a full salary $(M=3.48, \mathrm{SD}=2.20), t(628)=-17.47, \mathrm{p}<0.001, d=1.39$. Similarly, participants perceived a salary cessation to be more painful for the CEO $(M=4.64$, $\mathrm{SD}=1.98)$ than a full salary $(M=3.06, \mathrm{SD}=2.16), t(628)=-9.58, \mathrm{p}<0.001, d=$ 0.76 . Importantly, we again find that a salary cessation was perceived as more painful for retail employees $(M=6.10, \mathrm{SD}=1.50)$ than for the CEO $(M=4.64, \mathrm{SD}=1.98), t$ $(631)=10.45, \mathrm{p}<0.001, d=0.83$.

\section{Mediation analysis}

We conducted a moderated mediation analysis, with CEO salary as the moderator, to explore the indirect effect of perceived employee pain on the relationship between employee salary and willingness to buy. Overall, perceived pain of the employee had a significant indirect effect in both the paid fully CEO salary condition (indirect effect: $-0.71,95 \% \mathrm{CI}[-0.96,-0.50])$ and the cut fully CEO salary condition (indirect effect: $-0.69,95 \%$ CI $[-0.96,-0.46])$. Thus, perceptions of retail employee pain mediated our results. The effect was not moderated by the CEO salary condition (index of moderated mediation: $-0.02,95 \%$ CI $[-0.18,0.15]$ ); perceived pain of the employee had a significant indirect effect on willingness to buy, regardless of CEO pay decision. To determine which construct best predicted willingness to buy, we entered all four mediators - perceived pain of employees, perceived pain of 
CEO, perceived fairness of employee wages, and perceived fairness of CEO wages into the same moderated mediation model as above. We find that, across both CEO wage conditions, the indirect effect of perceived employee pain on the relationship between employee salary and willingness to buy (indirect effect CEO paid fully: $-0.64,95 \%$ CI $[-0.87,-0.46]$; indirect effect CEO cut fully: $-0.63,95 \%$ CI $[-0.86$, $-0.43]$; index of moderated mediation: $-0.02,95 \%$ CI $[-0.16,0.13])$ is greater than the indirect effects of perceived CEO pain (indirect effect CEO paid fully: $-0.06,95 \%$ CI $[-0.14,-0.01]$; indirect effect CEO cut fully: $-0.07,95 \%$ CI $[-0.17$, $0.01]$; index of moderated mediation: $0.01,95 \%$ CI $[-0.08,0.11])$, perceived fairness of employee wages (indirect effect CEO paid fully: $-0.26,95 \%$ CI $[-0.43,-0.14]$; indirect effect CEO cut fully: $-0.37,95 \%$ CI $[-0.57,-0.22]$; index of moderated mediation: $0.11,95 \%$ CI $[-0.03,0.29])$, and perceived fairness of CEO wages (indirect effect CEO paid fully: $-0.11,95 \%$ CI $[-0.23,-0.01]$; indirect effect CEO cut fully: $-0.24,95 \%$ CI $[-0.40,-0.12]$; index of moderated mediation: $0.14,95 \%$ CI $[0.00$, 0.32]). These results support the hypothesis that consumer's purchasing decisions are influenced more by perceived pain to employees than by perceptions of pain to the CEO or perceptions of wage fairness.

\section{Discussion}

Study 2 shows that regardless of the status of the CEO salary, consumers were significantly more likely to purchase from a firm that continued to pay retail salaries throughout the crisis. Indeed, we find that perception of employee pain is a stronger predictor of willingness to buy, suggesting that, during times of crisis and looming loss, consumers care more about maintaining employee pay than they do about the fairness of pay ratios.

\section{Study 3}

The key objective of Study 3 is to examine whether revealing employee salary cessations versus CEO salary cuts affects consumer behavior in an incentive-compatible context. While Studies 1 and 2 investigated the effects of full salary cuts for employees versus CEOs, Studies 3 and 4 test full employee pay cuts versus partial CEO pay cuts, as this was a more typical firm decision during the pandemic (DiNapoli \& Kerber, 2020). In this study, participants read about four different 'masked' firms, accompanied by varying descriptions but no brand names, and were asked to choose which firm they would like to receive a $\$ 50$ gift card to an actual lottery. Participants were either given no additional information or were given full information about the firms' salary decisions for retail employees and CEO. In this study, we also included a multi-item willingness-to-buy measure (Spears \& Singh, 2004) to measure the preference for each company, as well as a hypothesis guess question to assess the role of demand effects.

\section{Method}

\section{Design and participants}

Participants $(N=404 ; 49 \%$ female; age: $M=38.69$ years, $\mathrm{SD}=11.75)$ were recruited through Amazon Mechanical Turk and paid a flat rate for compensation. Study 3 
used a two-condition, between-subject design. All participants were given initial instructions that they were going to read descriptions about four different companies and be asked which company they would prefer to buy from. In the no disclosure (control) condition, participants read a description of each company (A, B, C, and D), including what items they sell and how many locations they have (e.g. 'Company $\mathbf{A}$ is a nationwide chain of retail stores that sells apparel in-store and online. Company A's products mainly comprise apparel and footwear, accessories, fine and fashion jewelry, home furnishings, and beauty products'; 'Company B is a nationwide chain of retail stores that sells apparel in-store and online. Company B sells moderately priced private-label and national brand clothing, shoes, accessories, cosmetics, and home furnishings'; full descriptions of each company are provided in Supplementary Material). In the disclosure condition, participants read additional information about each company. They read that 'due to the COVID-19 epidemic,' Company A 'decided to continue to pay their CEO's full salary, and no longer pay their retail employees' salaries,' Company B 'decided to cut their CEO's salary, and no longer pay their retail employees' salaries,' Company $\mathrm{C}$ 'decided to continue to pay their CEO's full salary, and continue to pay their retail employees' salaries,' and Company D 'decided to cut their CEO's salary, and continue to pay their retail employees' salaries.'

\section{Measure}

All participants rated their intent to purchase a discounted gift card to each of the four companies across a five-item scale using a 7-point semantic differential (e.g., 'Very low purchase interest'; 'Very high purchase interest') adapted from Spears and Singh $(\alpha=0.98 ; 2004)$. Then, participants were told 'You have the opportunity to be entered into a draw for a chance to win a $\$ 50$ gift card for EITHER Company A, $\mathrm{B}, \mathrm{C}$, or D. It is your choice whether to be entered for the draw. Please make your selection below. If you win the gift card draw, then we will give you the amount of the gift card. Your odds of winning the raffle are approximately 1 in 400.' Participants then chose which of the four retailers they would want a gift card to if they won the lottery. Finally, participants were asked to guess the hypothesis of the study from a multiple-choice question, including one right answer, three incorrect answers, and the option to indicate 'I don't know.'

\section{Results}

\section{Purchase intention}

We ran a mixed ANOVA to analyze the effects of disclosure condition (betweensubjects), employee pay decision (within-subject), and CEO pay decision (withinsubject) on purchase intentions (see Figure 3). We find a significant main effect of disclosure condition, $F(1,402)=4.83, \mathrm{p}=0.03, \eta^{2}=0.01$, such that participants indicated reduced intentions to purchase when pay decisions were revealed $(M=3.94$, SE $=0.07)$ relative to the control condition $(M=4.17, \mathrm{SE}=0.07)$. We find a significant main effect of employee pay decision, such that participants were more intent on purchasing from firms that paid employees in full $(M=4.48, \mathrm{SE}=0.06)$ than from firms that cut employee pay fully $(M=3.64, \mathrm{SE}=0.07), F(1,402)=85.88, \mathrm{p}<0.001, \eta^{2}=$ 


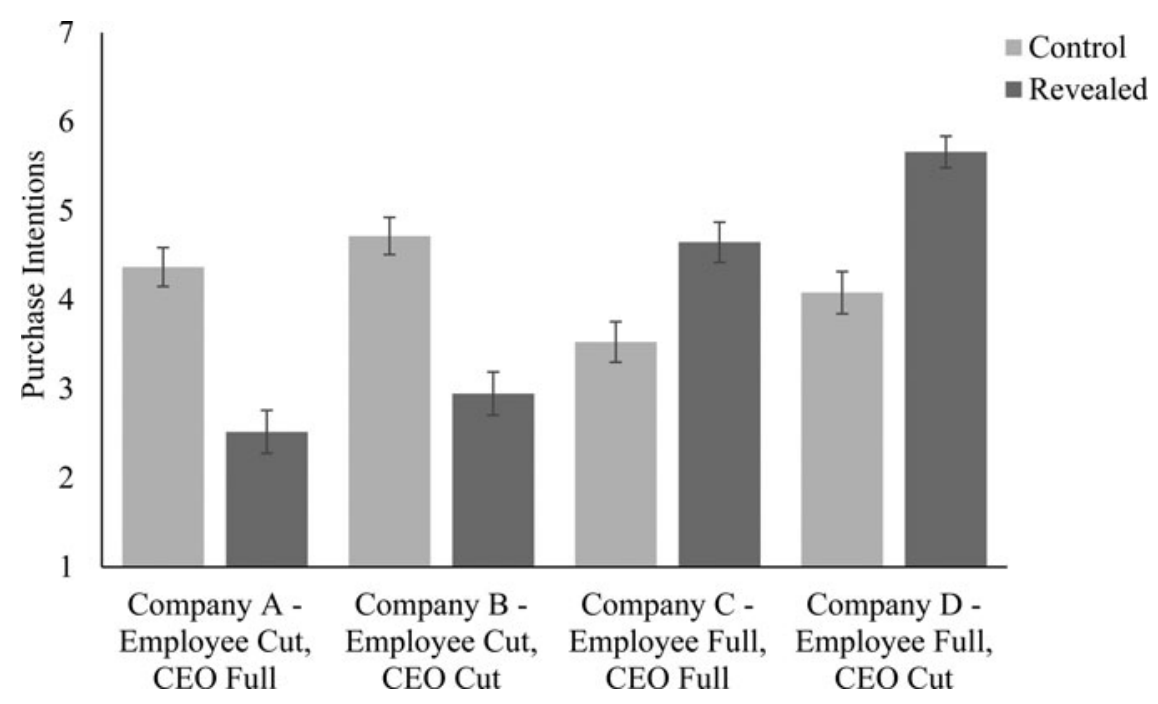

Figure 3. Effects of Disclosure on Purchase Intentions in Study 3. Error Bars Show $95 \% \mathrm{Cl}$.

0.18 . We also find a significant interaction between employee pay decision and the disclosure condition, $F(1,402)=303.04, \mathrm{p}<0.001, \eta^{2}=0.43$, such that participants were significantly less intent on purchasing from a company when it was disclosed that they decided to cease employee pay. We also find a significant main effect of CEO pay decision, such that participants were more intent on purchasing from firms that cut $\mathrm{CEO}$ pay $(M=4.35, \mathrm{SE}=0.05)$ than from firms that continue to pay CEOs fully $(M=3.77, \mathrm{SE}=0.06), F(1,402)=117.80, \mathrm{p}<0.001, \eta^{2}=0.22$. Again, we find a significant interaction between CEO pay decision and disclosure condition, $F(1,402)=6.25, \mathrm{p}=0.01, \eta^{2}=0.02$, such that participants were significantly more intent on purchasing from a company when it was disclosed that they decided to cut CEO pay. There was not a significant interaction between disclosure, employee pay decision, and CEO pay decision, $F(1,402)=2.61, \mathrm{p}=0.11, \eta^{2}=0.01$, such that participants reacted equally favorably to the companies that disclosed a choice to maintain employee pay, regardless of their CEO pay decision. See Supplementary Material S5 for the effect of disclosure on purchase intention for each company.

\section{Choice of gift card}

Given the structure of our data (gift card choice as a four-level categorical DV and condition as a categorical predictor), we ran a multinomial logistic regression to examine the effect of disclosure on gift card choice. The model for the overall data set was significant $\chi^{2}(3)=50.96 ; \mathrm{p}<0.001$; see Table 1 for full results). In this regression, the disclosure condition was included as a predictor, with the control (no disclosure) condition as the dummy level, and thus significance tests are run in comparison to no disclosure control. The company that decided to continue to pay both their CEO's full salary and their retail employees' full salaries (Company A) is used as the reference group for gift card choice. We find that participants in the 
Table 1. Multinomial logistic regression estimates.

\begin{tabular}{|c|c|c|c|c|c|}
\hline Variables & $B(\mathrm{SE})$ & $\begin{array}{c}\text { Wald } \\
\chi^{2}\end{array}$ & $p$ & $\begin{array}{l}\text { Odds } \\
\text { ratio Exp } \\
(B)\end{array}$ & $\begin{array}{l}95 \% \text { Confidence } \\
\text { interval for } \operatorname{Exp}(B)\end{array}$ \\
\hline \multicolumn{6}{|l|}{ Gift card choice ${ }^{a}$} \\
\hline $\begin{array}{l}\text { Employee } \\
\text { Cut and CEO } \\
\text { Full }\end{array}$ & $-2.507(0.416)$ & 36.268 & $<.001$ & 0.082 & {$[0.036,0.184]$} \\
\hline $\begin{array}{l}\text { Employee } \\
\text { Cut and CEO } \\
\text { Cut }\end{array}$ & $-2.212(0.386)$ & 32.929 & $<.001$ & 0.109 & {$[0.051,0.233]$} \\
\hline $\begin{array}{l}\text { Employee } \\
\text { Full and CEO } \\
\text { Cut }\end{array}$ & $-0.048(0.357)$ & 0.018 & 0.893 & 0.953 & {$[0.473,1.918]$} \\
\hline
\end{tabular}

${ }^{\mathrm{a}}$ The baseline levels were no disclosure condition and CEO Full and Employee Full.

disclosure condition were less likely to choose either of the companies that no longer paid employee salaries, relative to the company that maintained both employee and CEO pay. Furthermore, participants were no more likely to choose the company that cut the CEO pay in addition to paying employees in full, relative to the company that chose to pay both CEO and employee salaries in full. These results hold even when controlling for whether the hypothesis was guessed correctly or not. See Supplementary Material S5 for additional analysis in which we remove participants who correctly identified the hypothesis.

\section{Discussion}

In an incentive-compatible context, Study 3 shows that relative to a control condition in which no salary information was revealed, participants given information about company salary decisions were more likely to buy from companies that maintained employee salaries in full than companies that no longer paid employee salaries; moreover, participants were more likely to choose one of the companies that maintained retail employee salaries, regardless of those companies' CEO pay decisions. In addition, participants continued to respond positively to the firm that chose to maintain both CEO and employee pay, even when doing so effectively maintains the CEO-to-worker pay ratio, suggesting that consumers are not only concerned with the ratio of CEO-to-employee pay, but are also responsive to information about the maintenance of employee salaries in times of crisis.

\section{Study 4}

Study 4 assesses whether these results hold in a non-COVID context. We show that, outside the context of COVID-19, consumers continue to react favorably to firms that maintain employee pay; but this effect is stronger when the firm also cuts CEO pay thus reducing the CEO-to-worker pay ratio. 


\section{Method}

\section{Design and participants}

Participants $(N=402$; $52 \%$ female; age: $M=40.35$ years, $\mathrm{SD}=12.37)$ were recruited through Amazon Mechanical Turk and paid a flat rate for compensation. Study 4 used a two-condition, between-subject design. All participants were given initial instructions that they were going to read a description about four different companies and be asked which company they would prefer to buy from. In the no disclosure (control) condition, participants read the same descriptions from Study 3 about each of the four different companies (A, B, C, and D), including information about what types of items each company sells and how many locations they have (see Supplementary Materials for the unique description of each companies). In the disclosure condition, participants read additional information about each company. They read that 'A few years ago, this company failed to reach its earning goals due to poor performance,' so Company A 'decided to continue to pay their CEO's full salary, and no longer pay their retail employees' salaries,' Company B 'decided to cut their CEO's salary, and no longer pay their retail employees' salaries,' Company C 'decided to continue to pay their CEO's full salary, and continue to pay their retail employees' salaries,' and Company D 'decided to cut their CEO's salary, and continue to pay their retail employees' salaries.'

\section{Measure}

All participants rated their intent to purchase a discounted gift card to each of the four companies using the same five-item scale as Study $3(\alpha=0.98)$.

\section{Results}

\section{Purchase intentions}

Again, we ran a mixed ANOVA to analyze the effects of disclosure condition (between-subjects), employee pay decision (within-subject), and CEO pay decision (within-subject) on purchases intentions (see Figure 4). We find a significant main effect of disclosure condition, $F(1,400)=25.31, \mathrm{p}<0.001, \eta^{2}=0.06$, such that participants indicated reduced intentions to purchase when pay decisions were revealed $(M=3.80, \mathrm{SE}=0.08)$ relative to the control condition $(M=4.37, \mathrm{SE}=0.08)$. We find a significant main effect of employee pay decision, such that participants were more interested in firms that paid employees in full $(M=4.52, \mathrm{SE}=0.07)$ than firms that no longer pay employee salaries $(M=3.65, \mathrm{SE}=0.07), F(1,400)=92.40$, $\mathrm{p}<0.001, \eta^{2}=0.19$. We find a significant interaction between employee pay decision and disclosure condition, $F(1,400)=226.08, \mathrm{p}<0.001, \eta^{2}=0.36$, such that participants were significantly less intent on purchasing from a company when it was disclosed that they decided to no longer pay employee salaries. We also find a significant main effect of CEO pay decision, such that participants were more intent on purchasing from the firms that cut CEO pay $(M=4.32, \mathrm{SE}=0.06)$ than firms that pay CEOs in full $(M=3.85, \mathrm{SE}=0.04), F(1,400)=78.33, \mathrm{p}<0.001, \eta^{2}=0.16$. Again, we find an interaction between $\mathrm{CEO}$ pay decision and disclosure condition, $F(1,400)=$ $17.22, \mathrm{p}<0.001, \eta^{2}=0.16$, such that participants were significantly more intent on purchasing from a company when it was disclosed that they decided to cut CEO 


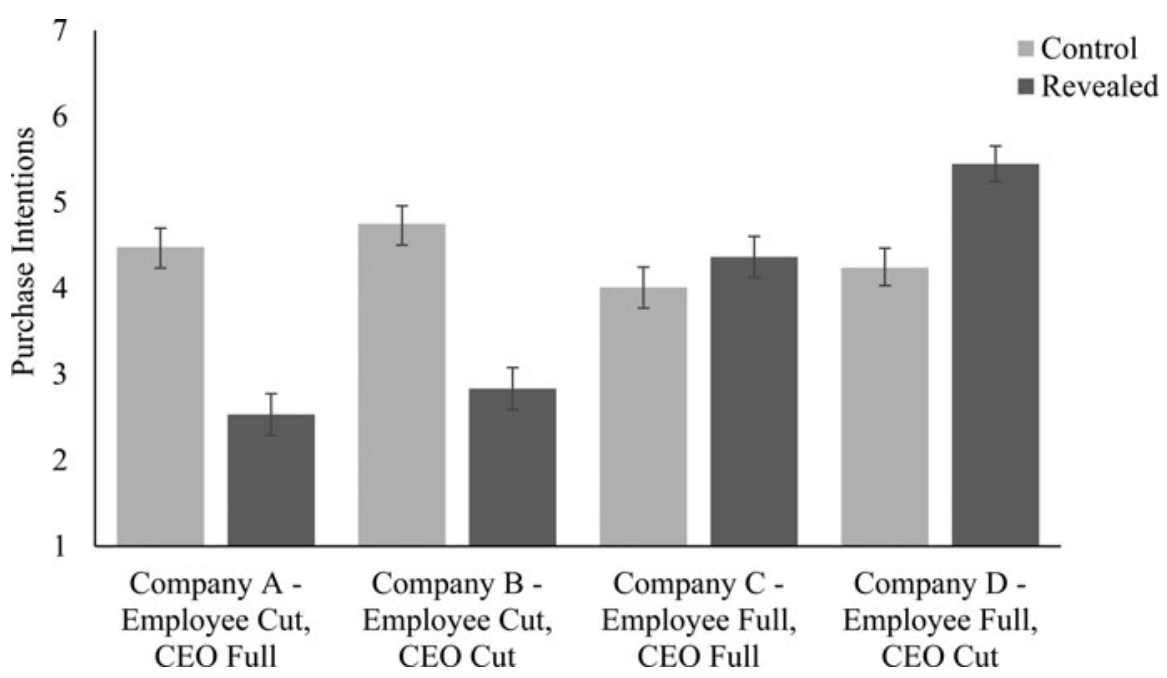

Figure 4. Effects of Disclosure on Purchase Intentions in Study 4. Error Bars Show 95\% Cl.

pay. Importantly, we find significant interaction between disclosure, employee pay decision, and CEO pay decision, $F(1,400)=15.90, \mathrm{p}<0.001, \eta^{2}=0.04$, such that in the disclosure condition there was a significantly larger positive effect for the company that chose to maintain employee pay and cut CEO pay relative to the company that maintained both employee and CEO pay. See Supplementary Material S5 for the effect of disclosure on purchase intention for each company.

\section{Discussion}

In Study 4, we again find that participants reacted favorably to both companies that chose to maintain employee pay. However, absent news of an external crisis, there was an added benefit of cutting CEO pay if employee pay was maintained. Therefore, while previous studies showed no, or limited, additional benefit to cutting CEO pay, these results show that, absent an external crisis, when unemployment risks are less salient, consumers do favor companies that pay employees and cut CEO pay, thereby reducing the CEO-to-worker pay ratio (Benedetti \& Chen, 2018; Mohan et al., 2018).

\section{General discussion}

Four experiments examine the impact of firm pay decisions for executives versus employees on consumer behavior. A firm's commitment to paying employees their full wages leads to the most positive consumer reactions (Study 1). When evaluating $\mathrm{CEO}$ and employee pay strategies simultaneously, consumers respond most positively to firms which prioritize paying employees, regardless of their strategy for CEO pay. Moreover, these positive perceptions are mediated by perceptions of financial pain to employees, more than perceptions of CEO-to-worker pay ratio fairness (Studies 1 and 
2). We replicate these effects in an incentive-compatible study (Study 3). Beyond the context of COVID-19, consumers continue to react favorably to firms that maintain employee pay, but there is an added benefit of cutting CEO pay and lowering the CEO-to-worker pay ratio.

These findings contribute to the current literature on consumer responses to employee pay and CEO-to-worker pay ratios (Benedetti \& Chen, 2018; Mohan et al., 2018). While previous research found that consumers prefer firms that reduce the CEO-to-worker pay ratio, these studies do not examine the extent to which consumer preferences are driven by the treatment of employees versus the treatment of CEO, particularly with respect to pay cuts and furloughs. This research, therefore, extends previous findings by demonstrating that a firm's treatment of its employees - specifically, the decision not to lay off or furlough employees without pay - may matter more to consumers than cuts or cessations to executive pay, even when those executive pay cuts lead to a lower CEO-to-worker pay ratio. Our findings suggest that this effect will be particularly true when loss of wages is salient to consumers, such as during the COVID-19 pandemic.

Our research provides an initial understanding of the effect of pay cessations for employees versus CEOs on consumers, but there is more room for future research on when and why these effects arise. We demonstrated a mediating role for pain caused to the employee, and show that the results hold when controlling for individual wages lost, but future research can explore how other individual-level attributes (such as political affiliation) or firm-level attributes (such as the firm's CEO pay ratio prior to the pay cut) may moderate our results (Mohan et al., 2018).

Moreover, future work can examine whether CEOs can take additional actions to mitigate the pain felt by employees, such as offering sick leave or paying for medical benefits (Morgan, 2020). Future work can also examine whether firms can recapture lost goodwill from consumers, by re-hiring furloughed employees, providing bonuses, or increasing pay (Danziger, 2020).

Our results have repercussions for policy-related decision-making. While the first coronavirus stimulus bill was being negotiated in 2020 , potential voters were surveyed about hypothetical preconditions for companies to qualify for bailout money (Stewart, 2020). Of these preconditions (which included a board seat for workers, protection of collective bargaining, and a guaranteed minimum wage), the condition that garnered the highest level of support was a commitment to no layoffs (Sheyman et al., 2020). In fact, this precondition received more support than the second most popular condition, which limited the compensation of CEOs of firms receiving bailout money (Stewart, 2020). Thus, policies that incentivize firms to preserve employee pay during a crisis may have implications for retaining not only the spending of customers but also the goodwill of voters.

The longer-term effects of efforts to prioritize employee jobs and pay are yet to be determined. However, a firm's decision to support their employees, upon disclosure, can be publicized by the news media, activist groups, politicians, and competitors. Thus, consumer-facing firms who prioritize paying their employees could gain equity as a result of greater customer awareness.

Supplementary material. To view supplementary material for this article, please visit https://doi.org/10. 1017/bpp.2021.30. 


\section{References}

AFL-CIO (2019), Executive Paywatch. Retrieved from: https://aflcio.org/paywatch.

Anderson, S. and S. Pizzigati (2020), Why CEO pay belongs at the center of the coronavirus bailout debate. MarketWatch. Retrieved from: https://www.marketwatch.com/story/why-ceo-pay-belongs-at-the-centerof-the-coronavirus-bailout-debate-2020-03-26.

Benedetti, A. H. and S. Chen (2018), 'High CEO-to-worker pay ratios negatively impact consumer and employee perceptions of companies', Journal of Experimental Social Psychology, 79: 378-393.

Brenan, M. (2020), Record-high $25 \%$ of U.S. workers say job loss is likely. Gallup. Retrieved from: https:// news.gallup.com/poll/308960/record-high-workers-say-job-loss-likely.aspx.

Bureau of Labor Statistics (2021), The employment situation - December 2020. Retrieved from: https:// www.bls.gov/news.release/pdf/empsit.pdf.

Campbell, A. F. (2019), CEOs made 287 times more money last year than their workers did. Vox. Retrieved from: https://www.vox.com/policy-and-politics/2019/6/26/18744304/ceo-pay-ratio-disclosure-2018.

Cappiello, E. (2020), 26 stores that promise to keep paying employees amid coronavirus closures. Reader's Digest. Retrieved from: https://www.rd.com/culture/stores-paying-employees-during-coronavirus/.

Chochrek, E. (2020), Kohl's to furlough workers, CEO to forfeit salary as coronavirus closures drag on. Footwear News. Retrieved from: https://footwearnews.com/2020/business/retail/kohls-furloughs-workers-ceo-forfeits-salary-coronavirus-1202956895/.

Creyer, E. H. and W. T. Ross (1996), 'The impact of corporate behavior on perceived product value', Marketing Letters, 7(2): 173-185.

Danziger, P. N. (2020), Essential retailers need to pay their essential employees fairly, not just during but after coronavirus. Forbes. Retrieved from: https://www.forbes.com/sites/pamdanziger/2020/04/08/essential-retailers-need-to-reward-their-essential-employees-not-just-during-but-after-coronavirus/.

de León, R. and J. Geller (2020), Here's how every major workforce has been impacted by the coronavirus pandemic. CNBC. Retrieved from: https://www.cnbc.com/2020/03/13/workforce-wire-coronavirusheres-what-every-major-company-is-doing-about-the-pandemic.html.

DiNapoli, J. and R. Kerber (2020), U.S. firms shield CEO pay as pandemic hits workers, investors. Reuters. Retrieved from: https://www.reuters.com/article/us-health-coronavirus-ceopay-insight/u-s-firms-shieldceo-pay-as-pandemic-hits-workers-investors-idUSKBN2341N9.

Gould, E. (2019), State of working America wages 2018: Wage inequality marches on and is even threatening data reliability. Economic Policy Institute. Retrieved from: https://www.epi.org/publication/state-ofamerican-wages-2018.

Hiscox, M. J., M. Broukhim and C. Litwin (2011), Consumer demand for fair trade: New evidence from a field experiment using eBay auctions of fresh roasted coffee. Harvard University. Working Paper.

Horowitz, J. (2020), The global coronavirus recession is beginning. CNN. Retrieved from: https:/edition. cnn.com/2020/03/16/economy/global-recession-coronavirus/index.html.

Kiatpongsan, S. and M. I. Norton (2014), 'How much (more) should CEOs make? A universal desire for more equal pay', Perspectives on Psychological Science, 9(6): 587-593.

Lee, A. (2020), Columbia Sportswear CEO takes pay cut to help support employees during coronavirus crisis. CNN. Retrieved from: https://edition.cnn.com/2020/03/29/business/tim-boyle-columbia-sportswearsalary-coronavirus-trnd/index.html.

McGregor, J. (2013), What's the right ratio for CEO-to-worker pay? The Washington Post. Retrieved from: http://www.washingtonpost.com/blogs/on-leadership/wp/2013/09/19/whats-the-right-ratio-for-ceo-toworker-pay/.

Mishel, L. and J. Wolfe (2019), CEO compensation has grown 940\% since 1978. Economic Policy Institute. Retrieved from: https://www.epi.org/publication/ceo-compensation-2018/.

Mohan, B., T. Schlager, R. Deshpandé and M. I. Norton (2018), 'Consumers avoid buying from firms with higher CEO-to-worker pay ratios', Journal of Consumer Psychology, 28(2): 344-52.

Morgan, B. (2020), 50 ways companies are giving back during the coronavirus pandemic. Forbes. Retrieved from: https://www.forbes.com/sites/blakemorgan/2020/03/17/50-ways-companies-are-giving-back-during-the-corona-pandemic/.

Paharia, N., K. D. Vohs and R. Deshpandé (2013), 'Sweatshop labor is wrong unless the shoes are cute: Cognition can both help and hurt moral motivated reasoning', Organizational Behavior and Human Decision Processes, 121(1): 81-88. 
Peloza, J., K. White and J. Shang (2013), 'Good and guilt-free: The role of self-accountability in influencing preferences for products with ethical attributes', Journal of Marketing, 77(1): 104-19.

Prasad, M., H. Kimeldorf, R. Meyer and I. Robinson (2004), 'Consumers of the world unite: A market-based response to sweatshops', Labor Studies Journal, 29(3): 57-79.

Sheyman, I., E. Winter and J. Coblentz (2020), The need for accountable bailouts: Warren's bailout conditions are both necessary and popular. Files for Progress. Retrieved from: http://filesforprogress.org/ memos/accountable-bailouts.pdf.

Smith, C. (2020), J.C. Penney joins Macy's, Gap, and other retailers to furlough thousands of workers without pay. Barron's. Retrieved from: https://www.barrons.com/articles/macys-gap-and-kohls-furloughthousands-of-workers-51585617549.

Spears, N. and S. N. Singh (2004), 'Measuring attitude toward the brand and purchase intentions', Journal of Current Issues \& Research in Advertising, 26(2): 53-66.

Stewart, E. (2020), Poll: Americans want corporations to promise no layoffs in exchange for bailouts. Vox. Retrieved from: https://www.vox.com/policy-and-politics/2020/3/23/21191502/coronavirus-stimulusbill-bailout-steve-mnuchin-democrats-elizabeth-warren.

Tarki, A., P. Levy and J. Weiss (2020), The Coronavirus crisis doesn't have to lead to layoffs. Harvard Business Review. Retrieved from: https://hbr.org/2020/03/the-coronavirus-crisis-doesnt-have-to-lead-tolayoffs.

Trentmann, N. and K. Broughton (2020), Companies that don't cut executive pay now could pay for it later. Wall Street Journal. Retrieved from: https://www.wsj.com/articles/companies-that-dont-cut-executivepay-now-could-pay-for-it-later-11587477361.

Vasel, K. (2020), What does it mean to be furloughed? CNN. Retrieved from: https://edition.cnn.com/2020/ 04/01/success/what-is-a-furlough/index.html.

Cite this article: Hagerty SF, Mohan B, Norton MI (2021). Whose pay should be cut in economic crises? Consumers prefer firms that prioritize paying employees over CEOs. Behavioural Public Policy 1-18. https://doi.org/10.1017/bpp.2021.30 